\title{
New biochars from raspberry and potato stems absorb more methane than wood offcuts and sunflower husk biochars**
}

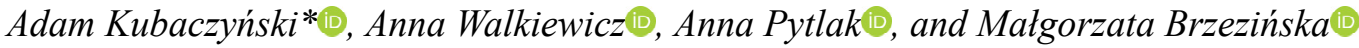 \\ Institute of Agrophysics, Polish Academy of Sciences, Doświadczalna 4, 20-290, Lublin, Poland
}

Received July 20, 2020; accepted August 25, 2020

\begin{abstract}
The reduction in greenhouse gas emissions from agriculture is of particular importance at present. In recent times, biochar addition to the soil was suggested as a means of mitigating greenhouse gases emissions from arable fields. More specifically, biochars with useful properties and those produced from easily available waste materials are still being sought. In the presented experiment, the $\mathrm{CH}_{4}$ absorption potential of four biochars incubated at 60 and $100 \%$ water holding capacity with the addition of $1 \% \mathrm{CH}_{4}(\mathrm{v} / \mathrm{v})$ was investigated for 28 days at $25^{\circ} \mathrm{C}$. The potato stem and raspberry stem biochars showed much higher potentials for $\mathrm{CH}_{4}$ uptake than wood offcuts biochar and sunflower husk biochar. Potato stem and raspberry stem biochars incubated at $60 \%$ water holding capacity were characterized by a methane uptake rate of $8.01 \pm 0.47$ and $5.78 \pm 0.17 \mathrm{mg} \mathrm{CH}_{4}-\mathrm{C} \mathrm{kg}^{-1} \mathrm{~d}^{-1}$, respectively. The methane removal potentials of the other biochars were clearly lower. The advantage of the biochars from raspberry and potato stems over the wood offcuts biochar also results from their significantly lower production of carbon dioxide. Consequently, these materials have a high potential for agricultural use, in view of their impact on the greenhouse gas balance of the soil.

Keywords: biochar, methane, greenhouse gas removal, raspberry stems, potato stems
\end{abstract}

\section{INTRODUCTION}

Biochar may be defined as biomass that has been pyrolysed in a zero or low oxygen environment (Lehmann and Rondon, 2006). The application of biochar to soil is expected to enhance soil fertility, improve its water reten-

*Corresponding author e-mail: a.kubaczynski@ipan.lublin.pl

**This work was partially conducted as a part of the project "Water in soil - satellite monitoring and improving the retention using biochar" no. BIOSTRATEG3/345940/7/NCBR/2017 which was financed by Polish National Centre for Research and Development within the framework of "Environment, agriculture and forestry" BIOSTRATEG strategic R\&D programme (2018-2020). tion properties and increase carbon sequestration (Coomes and Miltner, 2017; Luo et al., 2016). Biochar addition may also stimulate soil microbial activity and reduce the emission of greenhouse gases (GHGs) such as carbon dioxide $\left(\mathrm{CO}_{2}\right)$ and methane $\left(\mathrm{CH}_{4}\right)(\mathrm{Wu}$ et al., 2019) due to its specific properties, such as a large surface area and its high porosity value (Jeffery et al., 2016; Kammann et al., 2017; Sokołowska et al., 2020). Oxygen in the soil environment is crucial for the functioning of microbiota and plant roots (Lehmann et al., 2011; Yang et al., 2017). A high degree of oxygen uptake by biochar may lead to the development of anoxic microhabitats in the soil (Ribas et al., 2019). Under such conditions, methane is formed by anaerobic microbiota and released to the atmosphere rather than being removed from it (Chistoserdova and Kalyuzhnaya, 2018). Moisture levels modify the air-water conditions and a range of between 50 and 70\% water holding capacity (WHC) is considered optimal for gas diffusion and soil microbiota (Walkiewicz et al., 2020a). On the other hand, temporary flooding also occurs which results in a reduction in gas diffusion (Yu et al., 2012). In order to mirror the variable conditions of the soil environment, we used 60 and $100 \%$ WHC. It has already been reported that the water held in the pores of the biochar may lead to a decrease in the amount of methane absorbed (Farzad et al., 2007). For this reason, it is important to test biochars (especially those produced from new feedstocks) at different moisture levels.

(C) 2020 Institute of Agrophysics, Polish Academy of Sciences (c) (1)(9) 
Biochar is increasingly used in environmental protection as a low-cost sorbent of heavy metals and hazardous gases (La et al., 2018; Xiong et al., 2019). Additionally, $\mathrm{CH}_{4}$ can be removed through biochar filtration (Syed et al., 2016). This gas is known for its explosive properties, which may pose a serious threat to safety in mines and landfills (Kammann et al., 2017; Pytlak et al., 2014), but mainly for its high infrared radiation absorption potential which results in a 28 -fold higher global warming potential than $\mathrm{CO}_{2}$ (IPCC, 2014). Nevertheless, there is an apparent deficit in studies describing the potential of biochar to remove higher than ambient $\mathrm{CH}_{4}$ concentrations (Huang et al., 2019; Syed et al., 2016).

Due to the growing number of biochar applications, modifications of established products, as well as new materials for its production are being sought (Kammann et al., 2017). New feedstocks could be a way to provide biochars with interesting and desirable properties (Thomazini et al., 2015; Tomczyk, 2020). Another advantage of biochar is that it can be produced from waste biomass, which for various reasons is not suitable for other purposes such as feed, litter or fuel production (Qi et al., 2020; Schwede et al., 2017). In these circumstances, the production of biochar is economically, environmentally and ethically justifiable. For this reason, we decided to study agricultural waste from potato and raspberry stems as potential feedstock for biochar production. Potato stems are left in the fields after harvest and raspberry bushes are trimmed and discarded after each growing season. According to the FAO, in 2007 the global area used to grow potatoes amounted to around 19.3 million ha. In Europe, 7.5 million hectares were used for this purpose and the cultivation area is still increasing (Mackay, 2009). Raspberry crops are less prevalent but they have a local significance. In 2010-2012, the average global area used for raspberry production was 92,000 hectares but the amount of stem biomass harvested per hectare was considerable (Zaremba, 2014). The availability of both potato and raspberry biomass is thus high. It should be noted that the stems are often a habitat for pathogenic microorganisms and parasites and for this reason they often have to be disposed of properly (Guo et al., 2019; Vincent et al., 2003). Biochar production may be a beneficial way of making biohazardous plant debris safe. In this way, hazardous waste biomass may be neutralized through pyrolysis and returned safely to the environment thereby contributing to carbon sequestration and a reduction in GHG emissions.

The new aspects of our study are: i) the utilization of new agricultural waste feedstocks, ii) performing experiments on a single biochar (usually biochar with soil was under investigation), iii) comprehensive approach which included monitoring $\mathrm{CH}_{4}, \mathrm{CO}_{2}$ and $\mathrm{O}_{2}$ exchange.

Since the ability of biochar to sequester $\mathrm{CH}_{4}$ may depend on the feedstocks used, we hypothesize that biochars produced from raspberry and potato stems may be used to remove $\mathrm{CH}_{4}$ from the atmosphere and that the process is moisture-dependent since a high water content may impair gas diffusion.

The aim of the study was to determine the potential of $\mathrm{CH}_{4}$ removal as well as the accompanying $\mathrm{CO}_{2}$ production and $\mathrm{O}_{2}$ uptake by new biochars prepared from plant waste materials (raspberry and potato stems) in comparison with widely available biochars made from wood offcuts and sunflower husks. In addition, we studied the differences between these materials based on their physicochemical properties.

\section{MATERIALS AND METHODS}

New biochars were produced in 2018 from raspberry (Br) and potato stems (Bp) (left after crop collection) by pyrolysis (at $600{ }^{\circ} \mathrm{C}$, for half an hour, in an $\mathrm{N}_{2}$ atmosphere), using an LAC L15/12 electric furnace with a Ht40 AL controller, and a working volume of $15 \mathrm{dm}^{3}$. After pyrolysis, nitrogen flushing was maintained until the furnace cooled to room temperature. Common biochars made from wood offcuts (Bo) and sunflower husks (Bs) were produced by New Technology Trade Ltd. (Kobylany, Poland) at a temperature of 600 and $550{ }^{\circ} \mathrm{C}$, respectively (Table 1).

All biochars were sieved with a $2 \mathrm{~mm}$ mesh sieve and stored in the dark at room temperature in hermetic containers. The content of the dissolved organic carbon (DOC), total carbon (TC) and nitrogen (TN), $\mathrm{pH}$, oxidation-reduction potential (Eh) and bulk density were measured before incubation (Table 1). The DOC content was measured with a TOC-VCPH analyser (Shimadzu, Japan) (Yu et al., 2018). The $\mathrm{pH}$ and $\mathrm{Eh}$ of the biochar were determined at a 1:5 biochar to water ratio, using a glass electrode and a redox electrode respectively (Sokołowska et al., 2020; Yoo et al., 2014) with a HQ40D Portable Multi Meter analyser (Hach Lange). The water holding capacity (WHC) of the tested biochars was determined according to Yoo et al. (2014) using the modified funnel method. The biochar $\mathrm{C}$ and $\mathrm{N}$ contents were determined using an elemental analyser (Perkin Elmer CHN 2400). The bulk density of the biochar was calculated based on its weight at $15^{\circ} \mathrm{C}$, at a volume of $10 \mathrm{~cm}^{3}$ (Özçimen and Karaosmanoğlu, 2004).

The tested biochars ( $5 \mathrm{~g}$ of air-dried biochar per sample in three replications) were weighed into $120 \mathrm{~cm}^{3}$ glass bottles and adjusted to $60 \%$ or $100 \%$ WHC by the addition of distilled water. All samples were closed and subjected to three days of preincubation at $25^{\circ} \mathrm{C}$. Next, after ventilation, the samples were closed with rubber stoppers and aluminum caps, and then the headspace was enriched with $1 \% \mathrm{CH}_{4}(\mathrm{v} / \mathrm{v})$ to improve analytical precision. During the following 28 days of incubation (at $25^{\circ} \mathrm{C}$, in darkness), the composition of the atmosphere $\left(\mathrm{CH}_{4}, \mathrm{CO}_{2}\right.$ and $\left.\mathrm{O}_{2}\right)$ above the biochar was analysed using a gas chromatograph. A GC-2014 (Shimadzu, Japan) gas chromatograph was used. It was fitted with a flame ionization detector (FID) 
Table 1. Characteristics of four biochars: wood offcuts biochar (Bo), sunflower husk biochar (Bs), raspberry stem biochar (Br) and potato stem biochar $(\mathrm{Bp})$

\begin{tabular}{|c|c|c|c|c|}
\hline \multirow{3}{*}{ Parameter } & \multicolumn{4}{|c|}{ Biochar } \\
\hline & Wood offcuts (Bo) & Sunflower husk (Bs) & Raspberry stem (Br) & Potato stem (Bp) \\
\hline & \multicolumn{2}{|c|}{$\begin{array}{l}\text { Common - produced by the local company } \\
\text { New Technology Trade Ltd., Kobylany, Poland }\end{array}$} & \multicolumn{2}{|c|}{$\begin{array}{l}\text { New - produced in the Institute of Agrophysics } \\
\text { PAS, Lublin, Poland }\end{array}$} \\
\hline Pyrolysis temperature $\left({ }^{\circ} \mathrm{C}\right)$ & 600 & 550 & 600 & 600 \\
\hline $\mathrm{C}$ content $(\%)$ & $86.13 \pm 0.24$ & $78.30 \pm 0.01$ & $74.21 \pm 0.34$ & $44.62 \pm 0.02$ \\
\hline $\mathrm{N}$ content $(\%)$ & $0.35 \pm 0.01$ & $0.98 \pm 0.03$ & $0.90 \pm 0.01$ & $1.35 \pm 0.00$ \\
\hline $\mathrm{C} / \mathrm{N}$ ratio & 246.09 & 79.90 & 82.46 & 33.05 \\
\hline DOC $\mathrm{mg} \mathrm{dm}^{-3}$ ) & $214.33 \pm 0.22$ & $106.57 \pm 2.77$ & $139.70 \pm 1.19$ & $100.04 \pm 0.24$ \\
\hline $\mathrm{pH}$ & $6.99 \pm 0.01$ & $9.19 \pm 0.02$ & $9.17 \pm 0.02$ & $9.60 \pm 0.05$ \\
\hline $\mathrm{Eh}(\mathrm{mV})$ & $105 \pm 0.36$ & $-16 \pm 0.17$ & $32 \pm 0.44$ & $25 \pm 0.46$ \\
\hline Bulk density $\left(\mathrm{g} \mathrm{cm}^{-3}\right)$ & $0.31 \pm 0.01$ & $0.35 \pm 0.01$ & $0.21 \pm 0.01$ & $0.19 \pm 0.01$ \\
\hline WHC $\left(\mathrm{g} \mathrm{H}_{2} \mathrm{O}\right.$ g biochar $\left.{ }^{-1}\right)$ & $2.58 \pm 0.26$ & $2.58 \pm 0.06$ & $4.31 \pm 0.16$ & $4.45 \pm 0.09$ \\
\hline
\end{tabular}

for $\mathrm{CH}_{4}$ and $\mathrm{CO}_{2}$ analysis and an electron capture detector (ECD) for $\mathrm{O}_{2}$. Poraplot $\mathrm{Q}$ and Restek Q-bond columns (column flow $-5 \mathrm{~cm}^{3} \mathrm{~min}^{-1}$, split ratio $5: 1$, oven temp. $-30^{\circ} \mathrm{C}$, injection volume $-150 \mu \mathrm{L}$, purge flow $3 \mathrm{~cm}^{3} \mathrm{~min}^{-1}$ ) with helium as a carrier was used to separate the gases. External standards $\left(1 \% \mathrm{CH}_{4}\right.$ in $\mathrm{He} ; 20.9 \% \mathrm{O}_{2}$ in $\mathrm{N}_{2}$, Air Products) were used for calibration (Walkiewicz et al., 2020a, 2020b).

The methane and oxygen uptake rates were determined based on the difference between the initial and final gas concentrations on the last incubation day, and divided by the time of apparent $\mathrm{CH}_{4}$ uptake (the lag phase for $\mathrm{CH}_{4}$ was excluded) (Eq. (1)). The carbon dioxide production rate was calculated similarly, but in this case the difference in $\mathrm{CO}_{2}$ concentration between the last and first incubation day was calculated due to the continuous emission of this gas (Eq. (2)) (Walkiewicz et al., 2020a):

$$
\mathrm{CH}_{4} \text { uptake rate }=\frac{C_{\text {initial }}-C_{\text {final }}}{t},
$$

$C_{\text {initial }}$ is the initial uptake $\mathrm{CH}_{4}$ concentration in the headspace ( $\left.\mathrm{mg} \mathrm{CH}_{4}-\mathrm{C} \mathrm{kg}^{-1}\right), C_{\text {final }}$ is the final $\mathrm{CH}_{4}$ concentration in the headspace $\left(\mathrm{mg} \mathrm{CH}_{4}-\mathrm{C} \mathrm{kg}^{-1}\right), t$ is the number of incubation days with $\mathrm{CH}_{4}$ uptake.

$$
\mathrm{CO}_{2} \text { production rate }=\frac{C_{\text {final }}-C_{\text {initial }}}{t},
$$

$C_{\text {final }}$ is the final $\mathrm{CO}_{2}$ concentration in the headspace ( $\mathrm{mg}$ $\left.\mathrm{CO}_{2}-\mathrm{C} \mathrm{kg}^{-1}\right), C_{\text {initial }}$ is the initial $\mathrm{CO}_{2}$ concentration in the headspace $\left(\mathrm{mg} \mathrm{CO}_{2}-\mathrm{C} \mathrm{kg}^{-1}\right)$, $\mathrm{t}$ is the number of incubation days.

Based on the final $\mathrm{CO}_{2}$ emission and $\mathrm{O}_{2}$ consumption, the $\mathrm{CO}_{2} / \mathrm{O}_{2}$ ratio was calculated for each biochar separately for $60 \%$ and $100 \% \mathrm{WHC}$, as a measure of biochar stability.

Net GWP was calculated by making a comparison between the cumulative $\mathrm{CH}_{4}$ and $\mathrm{CO}_{2}$ fluxes in $\mathrm{mg} \mathrm{CO}$ equivalent per $\mathrm{kg}$ of biochar (Walkiewicz et al., 2020b).
In these calculations, the GWP value for $\mathrm{CH}_{4}$ and $\mathrm{CO}_{2}$ was considered to be 28 and 1 , respectively, over a 100 -year time horizon (IPCC, 2014).

The results were statistically processed with Statistica 13 software (StatSoft Inc.). A one-way ANOVA (Tukey HSD post-hoc test) was used to test the significance of the differences in $\mathrm{CH}_{4}$ uptake and $\mathrm{CO}_{2}$ emission rates between the tested biochars (separately for 60 and $100 \%$ WHC).

\section{RESULTS}

For the group of four biochars incubated at $60 \%$ WHC, the added methane was completely taken up by the potato (Bp) and raspberry (Br) biochars (Fig. 1a). The most efficient in terms of $\mathrm{CH}_{4}$ removal were samples containing $\mathrm{Bp}$, where after a 13-day long lag phase, the $\mathrm{CH}_{4}$ uptake rate reached $8.01 \pm 0.47 \mathrm{mg} \mathrm{CH}_{4}-\mathrm{C} \mathrm{kg}^{-1} \mathrm{~d}^{-1}$, resulting in methane depletion within 25 days of incubation (Table 2). The incubation of $\mathrm{Br}$ showed a similar lag phase duration (15 days), and almost complete $\mathrm{CH}_{4}$ removal occurred 13 days later. The methane uptake rate for the raspberry stem biochar achieved $5.78 \pm 0.17 \mathrm{mg} \mathrm{CH}_{4}-\mathrm{C} \mathrm{kg}^{-1} \mathrm{~d}^{-1}$ at $60 \%$ WHC. Methane wasn't completely absorbed by sunflower husk biochar (Bs) and only ca. $11 \%(10.23 \pm 3.46 \mathrm{mg}$ $\mathrm{CH}_{4}-\mathrm{C} \mathrm{kg}^{-1}$ ) of the added $\mathrm{CH}_{4}$ was absorbed by the end of incubation (till the 28th day) after a $24 \pm 2$ days lag phase. The wood offcuts biochar (Bo) did not show any apparent ability for $\mathrm{CH}_{4}$ uptake at $60 \%$ WHC. Within the applied experimental timeframes, less than $1 \%$ of the added $\mathrm{CH}_{4}$ $\left(0.95 \pm 0.25 \mathrm{mg} \mathrm{CH}_{4}-\mathrm{C} \mathrm{\textrm {kg } ^ { - 1 }}\right)$ was removed by the wood offcuts biochar.

The tested biochars differed in the $\mathrm{CO}_{2}$ emissions that accompanied $\mathrm{CH}_{4}$ uptake (Fig. 1b), but special attention needs to be paid to the wood offcuts biochar. During the experiment, Bo produced several times more $\mathrm{CO}_{2}$ than the other biochars, with an average $\mathrm{CO}_{2}$ production rate as high as $19.98 \pm 1.22 \mathrm{mg} \mathrm{CO}_{2}-\mathrm{C} \mathrm{kg}^{-1} \mathrm{~d}^{-1}$. On the last day of incubation, $\mathrm{CO}_{2}$ concentration in Bo was ca. $573 \mathrm{mg} \mathrm{CO}_{2}-\mathrm{C} \mathrm{kg}^{-1}$, 

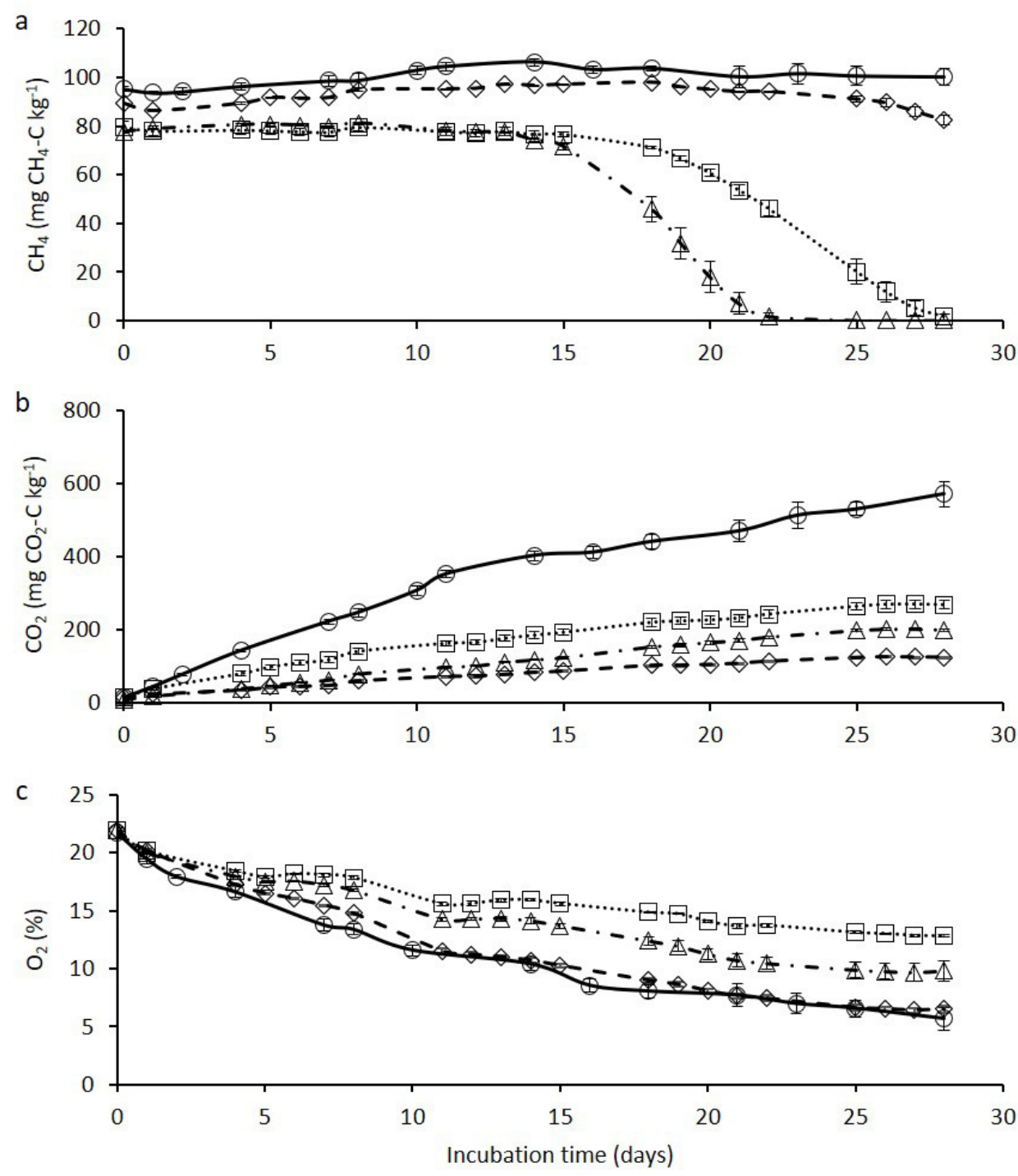

$$
\begin{array}{ll}
\longrightarrow \text { Wood offcuts biochar (Bo) } & -\diamond-\text { Sunflower husk biochar (Bs) } \\
\cdots . . \cdot \text { Raspberry stem biochar (Br) } & -\Delta-\text { Potato stem biochar (Bp) }
\end{array}
$$

Fig. 1. Uptake of added $\mathrm{CH}_{4}(1 \% \mathrm{v} / \mathrm{v})(\mathrm{a})$, which accompanies $\mathrm{CO}_{2}$ production (b) and $\mathrm{O}_{2}$ uptake (c) by four biochars produced from: wood offcuts (Bo), sunflower husks $(\mathrm{Bs})$, raspberry stems $(\mathrm{Br})$ and potato stems $(\mathrm{Bp})$ incubated at $60 \% \mathrm{WHC}(\mathrm{avg} . \pm \mathrm{SD}, \mathrm{n}=3)$.

Table 2. Methane uptake and accompanying carbon dioxide emission rate for the entire biochar incubation period with $1 \% \mathrm{CH}_{4}(\mathrm{v} / \mathrm{v})$

\begin{tabular}{cccccr}
\hline \multirow{2}{*}{ Biochar type } & \multicolumn{2}{c}{$\mathrm{CH}_{4}$ uptake rate $\left(\mathrm{mg} \mathrm{CH}_{4}-\mathrm{C} \mathrm{kg}^{-1} \mathrm{~d}^{-1}\right)$} & & \multicolumn{2}{c}{$\mathrm{CO}_{2}$ emission rate $\left(\mathrm{mg} \mathrm{CO}_{2}-\mathrm{C} \mathrm{kg}^{-1} \mathrm{~d}^{-1}\right)$} \\
\cline { 2 - 3 } \cline { 5 - 6 } & $60 \% \mathrm{WHC}$ & $100 \% \mathrm{WHC}$ & & $60 \% \mathrm{WHC}$ & $100 \% \mathrm{WHC}$ \\
\hline Bo & $0.17^{\mathrm{a}} \pm 0.06$ & $0.33^{\mathrm{A}} \pm 0.18$ & & $19.98^{\mathrm{c}} \pm 1.22$ & $21.62^{\mathrm{C}} \pm 1.32$ \\
Bs & $2.74^{\mathrm{b}} \pm 0.57$ & $1.51^{\mathrm{A}} \pm 0.55$ & & $3.88^{\mathrm{a}} \pm 0.08$ & $2.44^{\mathrm{A}} \pm 0.33$ \\
Br & $5.78^{\mathrm{c}} \pm 0.17$ & $3.03^{\mathrm{B}} \pm 0.35$ & & $9.05^{\mathrm{b}} \pm 0.40$ & $6.72^{\mathrm{B}} \pm 0.16$ \\
Bp & $8.01^{\mathrm{d}} \pm 0.47$ & $5.52^{\mathrm{C}} \pm 0.81$ & & $8.39^{\mathrm{b}} \pm 0.35$ & $2.55^{\mathrm{A}} \pm 0.04$ \\
\hline
\end{tabular}

Different letters indicate significant differences between biochars, separately for $60 \%$ (small letters) and 100\% WHC (capital letters), separately for $\mathrm{CH}_{4}$ and $\mathrm{CO}_{2}$, Tukey test, $\mathrm{p}<0.05$. 

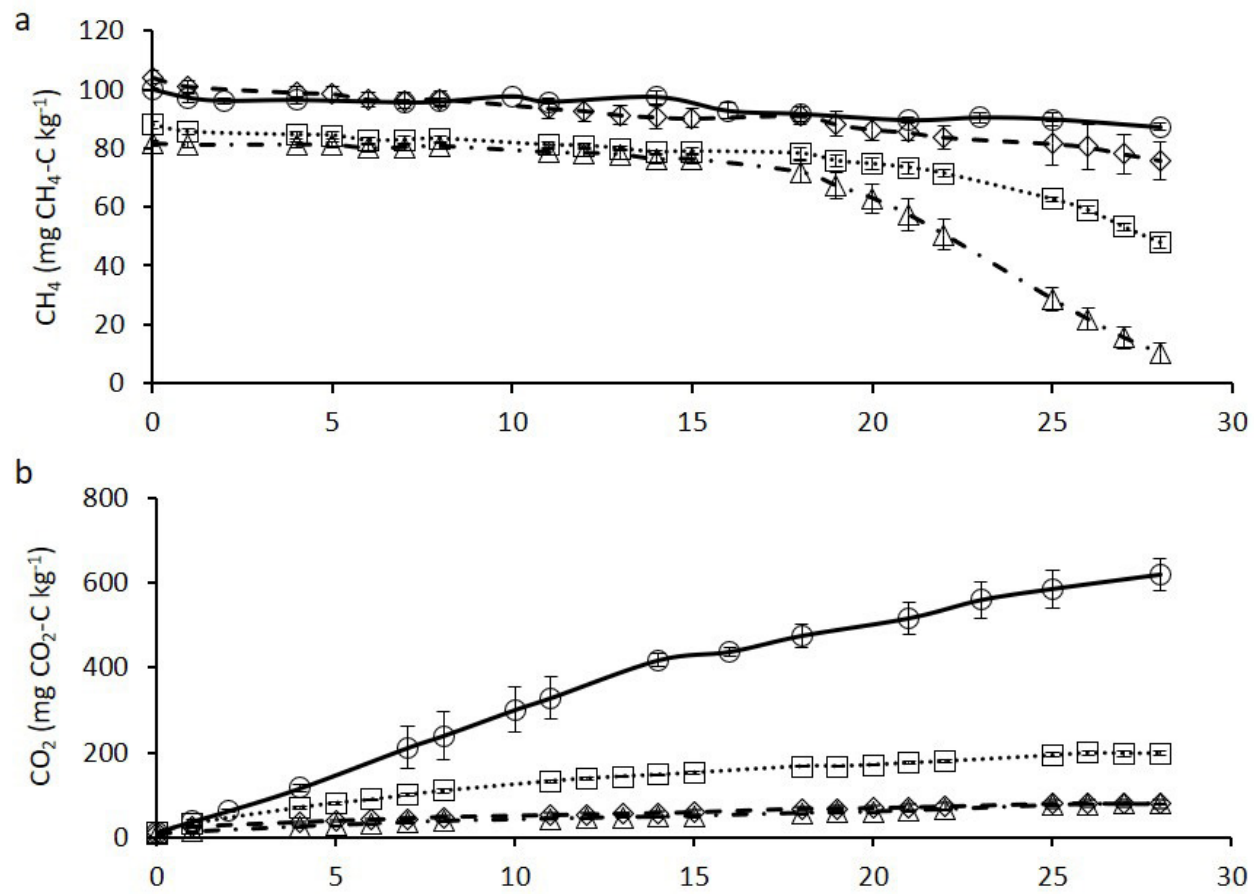

c
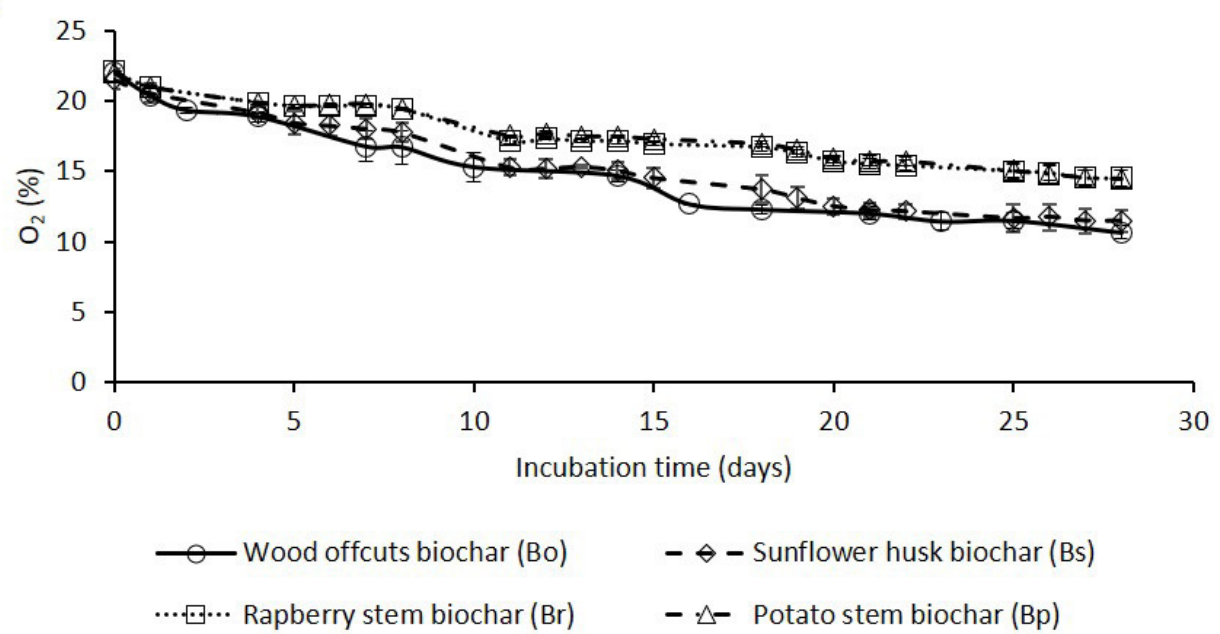

Fig. 2. Uptake of added $\mathrm{CH}_{4}(1 \% \mathrm{v} / \mathrm{v})(\mathrm{a})$, which accompanies $\mathrm{CO}_{2}$ production (b) and $\mathrm{O}_{2}$ uptake (c) by four biochars produced from: wood offcuts (Bo), sunflower husks (Bs), raspberry stems (Br) and potato stems (Bp) incubated at $100 \% \mathrm{WHC}(\mathrm{avg} . \pm \mathrm{SD}, \mathrm{n}=3)$.

while the $\mathrm{CO}_{2}$ concentration determined in the other tested biochars remained below $300 \mathrm{mg} \mathrm{CO}_{2}-\mathrm{C} \mathrm{kg}^{-1}$. The $\mathrm{Br}$ and Bp biochars showed similar dynamics and $\mathrm{CO}_{2}$ production rates (respectively: $9.05 \pm 0.40$ and $8.39 \pm 0.35 \mathrm{mg} \mathrm{CO}_{2}-\mathrm{C}$ $\left.\mathrm{kg}^{-1} \mathrm{~d}^{-1}\right)$. At $60 \%$ WHC moisture level, the production of $\mathrm{CO}_{2}$ was definitely lowest in Bs (with a rate of $3.88 \pm 0.08$ $\mathrm{mg} \mathrm{CO}-\mathrm{C} \mathrm{kg}^{-1} \mathrm{~d}^{-1}$ ) where the final concentration of this gas didn't exceed $130 \mathrm{mg} \mathrm{CO}-\mathrm{C} \mathrm{kg}^{-1}$.

The highest $\mathrm{CO}_{2}$ production by Bo corresponded to its highest $\mathrm{O}_{2}$ uptake. At $60 \%$ WHC, the differences in the $\mathrm{O}_{2}$ uptake of new biochar were clearly visible (Fig. 1c). During incubation, the oxygen level dropped to 12.8 and
9.8\% in $\mathrm{Br}$ and $\mathrm{Bp}$ respectively while for the $\mathrm{Bs}$ and $\mathrm{Bo}$ variants, the final $\mathrm{O}_{2}$ levels were as low as 6.5 and $5.7 \%$, respectively $(\mathrm{v} / \mathrm{v})$.

Biochars incubated at higher moisture levels (100\% WHC) showed different dynamics of $\mathrm{CH}_{4}$ uptake. Within the applied timeframes, none of the tested biochars absorbed all of the added $\mathrm{CH}_{4}$ (Fig. 2a). The lag phases were generally longer than at $60 \% \mathrm{WHC}$, and $\mathrm{CH}_{4}$ absorption was slower. Methane uptake rates in potato $(\mathrm{Bp})$ and raspberry (Br) stem biochar reached values of $5.52 \pm 0.81$ and 3.03 $\pm 0.35 \mathrm{mg} \mathrm{CH}_{4}-\mathrm{C} \mathrm{kg}^{-1} \mathrm{~d}^{-1}$, respectively (Table 2). The lag phases in the $\mathrm{Bp}$ and $\mathrm{Br}$ biochars lasted for about 16 and 18 days, respectively. The $\mathrm{CH}_{4}$ uptake rate by Bp was highest and resulted in a reduction of $87 \%$ in the added $\mathrm{CH}_{4}$. 
Table 3. Global warming potential (GWP) contributions from $\mathrm{CO}_{2}$ emission and $\mathrm{CH}_{4}$ uptake by biochars $(\mathrm{Bo}, \mathrm{Bs}, \mathrm{Br}$ and $\mathrm{Bp})$ incubated under 60 and $100 \%$ WHC (calculated based on GHGs data for the last incubation day)

\begin{tabular}{|c|c|c|c|c|}
\hline \multirow{2}{*}{ Biochar type } & \multirow{2}{*}{$\begin{array}{l}\text { Moisture } \\
\text { WHC (\%) }\end{array}$} & GWP-CO ${ }_{2}$ & GWP-CH $\mathrm{CH}_{4}$ & Net GWP \\
\hline & & \multicolumn{3}{|c|}{$\left(\mathrm{g} \mathrm{CO}_{2(\mathrm{eq})} \mathrm{kg}^{-1}\right)$} \\
\hline \multirow{2}{*}{ Bo } & 60 & $2.049^{d} \pm 0.125$ & $-0.035^{\mathrm{a}} \pm 0.009$ & $2.014^{c} \pm 0.120$ \\
\hline & 100 & $2.217^{\mathrm{C}} \pm 0.135$ & $-0.096^{\mathrm{A}} \pm 0.043$ & $2.122^{\mathrm{B}} \pm 0.100$ \\
\hline \multirow{2}{*}{ Bs } & 60 & $0.398^{\mathrm{a}} \pm 0.008$ & $-0.382^{b} \pm 0.129$ & $0.016^{\mathrm{a}} \pm 0.137$ \\
\hline & 100 & $0.250^{\mathrm{A}} \pm 0.034$ & $-0.565^{\mathrm{B}} \pm 0.204$ & $-0.315^{\mathrm{A}} \pm 0.217$ \\
\hline \multirow{2}{*}{$\mathrm{Br}$} & 60 & $0.928^{\mathrm{c}} \pm 0.041$ & $-2.805^{\mathrm{c}} \pm 0.082$ & $-1.876^{b} \pm 0.085$ \\
\hline & 100 & $0.690^{\mathrm{B}} \pm 0.016$ & $-1.131^{\mathrm{C}} \pm 0.130$ & $-0.441^{\mathrm{A}} \pm 0.115$ \\
\hline \multirow{2}{*}{$\mathrm{Bp}$} & 60 & $0.696^{b} \pm 0.012$ & $-2.883^{c} \pm 0.009$ & $-2.187^{d} \pm 0.021$ \\
\hline & 100 & $0.262^{\mathrm{A}} \pm 0.004$ & $-2.440^{\mathrm{D}} \pm 0.088$ & $-2.178^{C} \pm 0.091$ \\
\hline
\end{tabular}

Different letters indicate significant differences between biochars, separately for $60 \%$ (small letters) and 100\% WHC (capital letters), Tukey test, $\mathrm{p}<0.05$.

Despite a lower $\mathrm{CH}_{4}$ uptake rate than $\mathrm{Bp}, \mathrm{Br}$ was also able to remove a relatively large portion of the $\mathrm{CH}_{4}$ added ( $c a$. $39 \%$ of the initial level). Clearly, less $\mathrm{CH}_{4}$ was taken up by Bs and Bo, as at $100 \%$ WHC those biochars absorbed just $15.14 \pm 5.46 \mathrm{mg} \mathrm{CH}_{4}-\mathrm{C} \mathrm{kg}^{-1}$ (ca. $\left.17 \%\right)$ and $2.56 \pm 1.14 \mathrm{mg}$ $\mathrm{CH}_{4}-\mathrm{C} \mathrm{kg}^{-1}$ (ca. 3\%) respectively, after quite a long lag phase duration (18 days) (Fig. 2a).

The $\mathrm{CO}_{2}$ emissions of the new $\mathrm{Bp}$ and $\mathrm{Br}$ biochars at $100 \%$ WHC were also lower than at $60 \%$ WHC (Fig. 2b). The rate of $\mathrm{CO}_{2}$ emission by the wood offcuts biochar (Bo) was not significantly affected by the tested moisture conditions, it showed the highest production among the tested materials (Table 2). The $\mathrm{Br}$ biochar was characterized by a medium $\mathrm{CO}_{2}$ production rate $\left(6.72 \pm 0.16 \mathrm{mg} \mathrm{CO}-\mathrm{C} \mathrm{kg}^{-1}\right.$ $\left.\mathrm{d}^{-1}\right)$ (Table 2), but the final concentration didn't exceed 200 $\mathrm{mg} \mathrm{CO}{ }_{2}-\mathrm{C} \mathrm{kg}^{-1}$. At $100 \% \mathrm{WHC}$, the tested Bp and Bs showed similarly low $\mathrm{CO}_{2}$ production rates $(\mathrm{Bp}: 2.55 \pm 0.04 \mathrm{mg}$ $\mathrm{CO}_{2}-\mathrm{C} \mathrm{kg}^{-1} \mathrm{~d}^{-1}$ and Bs: $\left.2.44 \pm 0.33 \mathrm{mg} \mathrm{CO} \mathrm{CO}_{2}-\mathrm{C} \mathrm{kg}^{-1} \mathrm{~d}^{-1}\right)$. For these variants, the final gas concentration was below 100 $\mathrm{mg} \mathrm{CO} \mathrm{CO}_{2}-\mathrm{C} \mathrm{kg}^{-1}$. With regard to $\mathrm{O}_{2}$ uptake, under given conditions, it was highest in the Bo and Bs incubations, with significantly lower values in $\mathrm{Br}$ and $\mathrm{Bp}$ (Fig. 2c).

The $\mathrm{CO}_{2} / \mathrm{O}_{2}$ ratio at $60 \% \mathrm{WHC}$ had the following values: 0.65 (Bo), $0.23(\mathrm{Br}$ and $\mathrm{Bp}$ ) and $0.19(\mathrm{Bs})$. At 100\% WHC, the $\mathrm{CO}_{2} / \mathrm{O}_{2}$ ratio was generally lower than at $60 \%$ WHC: $0.45(\mathrm{Bo}), 0.15(\mathrm{Br}), 0.07(\mathrm{Bs})$ and $0.06(\mathrm{Bp})$.

The values of net GWP which were calculated for each biochar under the tested moisture conditions are presented in Table 3.

\section{DISCUSSION}

Biochar is currently the focus of attention for scientists worldwide as a useful and beneficial soil additive. To date, however, most studies have been focused on gas exchange and microbial activity in biochar mixed with soil (Han et al., 2016; He et al., 2017; Lehmann et al., 2011). Only a small group of studies have described the sole incubation of biochars. Moreover, those experiments were performed with the use of small portions of biochar (less than 1g) (Spokas and Reicosky, 2009; Thomazini et al., 2015). In those studies, the uptake of $\mathrm{CH}_{4}$ and $\mathrm{CO}_{2}$ emissions brought about by the biochar, could usually be explained by abiotic processes (Jeffery et al., 2016; Thomazini et al., 2015). In our study, we presented newly developed biochars from common agricultural wastes. To the best of our knowledge, these materials had not been considered at the time of writing.

The new biochars from raspberry and potato stems were prepared under comparable temperature conditions as widely available materials produced from common feedstocks (wood offcuts and sunflower husks) (Sokołowska et al., 2020; Zubkova et al., 2019). Considering their potential application to soil we determined their basic physicochemical properties (Table 1). It was found that the newly produced materials may improve the soil environment by increasing $\mathrm{C}$ and $\mathrm{N}$ content, the $\mathrm{pH}$ value (of acidic soils) and water storage ability (especially under drought conditions); this corresponds with current, global-scale problems. With respect to the aforementioned advantages, the newly developed biochars from raspberry $(\mathrm{Br})$ and potato $(\mathrm{Bp})$ stems seem to be even better than the well-known wood offcuts (Bo) and sunflower husk (Bs) biochars.

According to Thomazini et al. (2015), $\mathrm{CH}_{4}$ uptake by wood chip biochar (produced at $550^{\circ} \mathrm{C}$ ) wasn't observed, while $\mathrm{CO}_{2}$ emissions from this material were $24 \mathrm{mg} \mathrm{CO}$-C $\mathrm{kg}^{-1} \mathrm{~d}^{-1}$ (in moisture conditions of $0.3 \mathrm{~mL}$ water per $1 \mathrm{~g}$ biochar). In our study, the wood offcuts biochar showed a similar $\mathrm{CO}_{2}$ production rate $\left(19.98 \mathrm{mg} \mathrm{CO}_{2}-\mathrm{C} \mathrm{kg}^{-1} \mathrm{~d}^{-1}\right.$ at $60 \% \mathrm{WHC}$ and $21.62 \mathrm{mg} \mathrm{CO}_{2}-\mathrm{C} \mathrm{kg}^{-1} \mathrm{~d}^{-1}$ at $100 \% \mathrm{WHC}$ ) 
and $\mathrm{CH}_{4}$ uptake was also not observed. In contrast to this result, the potato stem biochar showed a three-fold lower $\mathrm{CO}_{2}$ production rate at $60 \% \mathrm{WHC}\left(8.39 \mathrm{mg} \mathrm{CO}_{2}-\mathrm{C} \mathrm{kg}^{-1} \mathrm{~d}^{-1}\right)$, while at $100 \% \mathrm{WHC}$ this rate was nearly 10 times lower ( $2.55 \mathrm{mg} \mathrm{CO} \mathrm{CO}_{2}-\mathrm{C} \mathrm{kg}^{-1} \mathrm{~d}^{-1}$ ) than that found in the Thomazini et al. (2015) study. At $60 \% \mathrm{WHC}$, the $\mathrm{CO}_{2}$ production rate of raspberry stem biochar $\left(9.05 \mathrm{mg} \mathrm{CO} \mathrm{CO}_{2}-\mathrm{C} \mathrm{kg}^{-1} \mathrm{~d}^{-1}\right)$ was at a similar level to Bp. Furthermore, potato stem and raspberry stem biochars also demonstrated a high level of $\mathrm{CH}_{4}$ removal.

Spokas and Reicosky (2009) tested 16 different biochars in terms of $\mathrm{CH}_{4}$ uptake and $\mathrm{CO}_{2}$ production. Only three wet biochars $\left(1 \mathrm{~mL} \mathrm{H}_{2} \mathrm{O}\right.$ per $0.5 \mathrm{~g}$ biochar) from this group showed an ability for $\mathrm{CH}_{4}$ uptake. Peanut hull biochar and corn stover biochar had an identical methane uptake rate ( $\left.2.6 \pm 0.6 \mathrm{n} \mathrm{CH}_{4} \mathrm{~g}^{-1} \mathrm{~d}^{-1}\right)$. The biochar whose feedstock was BiosourceTM showed the highest methane uptake rate of all ( $4.1 \pm 0.9 \mathrm{ng} \mathrm{CH}_{4} \mathrm{~g}^{-1} \mathrm{~d}^{-1}$ ). On the other hand, those biochars exhibited a high rate of $\mathrm{CO}_{2}$ production: peanut hull biochar $168.5 \pm 23.5 \mu \mathrm{g} \mathrm{CO}_{2} \mathrm{~g}^{-1} \mathrm{~d}^{-1}$; corn stover biochar 162.4 $\pm 15.0 \mu \mathrm{g} \mathrm{CO}_{2} \mathrm{~g}^{-1} \mathrm{~d}^{-1}$ and biochar with BiosourceTM as a feedstock produced as much as $1022.4 \pm 109 \mu \mathrm{g} \mathrm{CO}_{2} \mathrm{~g}^{-1} \mathrm{~d}^{-1}$ (Spokas and Reicosky, 2009). In our study, the methane uptake rate of the raspberry stem biochar at $60 \%$ WHC was $5.78 \pm 0.17 \mathrm{mg} \mathrm{CH}_{4}-\mathrm{C} \mathrm{kg}^{-1} \mathrm{~d}^{-1}$ (corresponding to $7706.66 \pm$ $226.66 \mathrm{ng} \mathrm{CH}_{4} \mathrm{~g}^{-1} \mathrm{~d}^{-1}$ ). The potato stem biochar at a similar moisture level showed an even higher rate at $8.01 \pm 0.47 \mathrm{mg}$ $\mathrm{CH}_{4}-\mathrm{C} \mathrm{kg}^{-1} \mathrm{~d}^{-1}$ (corresponding to $10680 \pm 626.66 \mathrm{ng} \mathrm{CH}_{4}$ $\left.\mathrm{g}^{-1} \mathrm{~d}^{-1}\right)$. Therefore, the methane uptake rates of the biochars were several thousand times higher than any biochar tested by Spokas and Reicosky (2009). It is important to note that during efficient methane absorption by biochar from raspberry and potato stems, $\mathrm{CO}_{2}$ emissions remained at a very low level. At $60 \% \mathrm{WHC}$, the average $\mathrm{CO}_{2}$ production rate from the raspberry stem biochar was $9.05 \pm 0.40 \mathrm{mg} \mathrm{CO}_{2}-\mathrm{C}$ $\mathrm{kg}^{-1} \mathrm{~d}^{-1}$ (corresponding to $33.15 \pm 1.47 \mu \mathrm{g} \mathrm{CO}_{2} \mathrm{~g}^{-1} \mathrm{~d}^{-1}$ ). The biochar that was the most effective at methane removal, the one made from potato stems, showed an even lower $\mathrm{CO}_{2}$ production rate, $8.39 \pm 0.35 \mathrm{mg} \mathrm{CO}_{2}-\mathrm{C} \mathrm{kg}^{-1} \mathrm{~d}^{-1}$ (corresponding to $\left.30.73 \pm 1.28 \mu \mathrm{g} \mathrm{CO}_{2} \mathrm{~g}^{-1} \mathrm{~d}^{-1}\right)$.

As yet, there are only a few studies describing the potential of biochars to remove $\mathrm{CH}_{4}$ present at higher than ambient concentrations. However, this is particularly important when considering the use of biochar as a gas sorbent in ecosystems with increased $\mathrm{CH}_{4}$ concentrations, such as those occurring in periodically waterlogged arable soils, paddy fields and landfills (Malyan et al., 2016; Reddy et al., 2014; Walkiewicz et al., 2020a). For this reason, we included a widely available biochar from common feedstock (Bo) in our experiment. However, Syed et al. (2016) conducted a long-term incubation of biochar from pine bark (prepared by pyrolysis at $450^{\circ} \mathrm{C}$ ) at changing $\mathrm{CH}_{4}$ concentrations. According to that study, non-inoculated biochar was able to remove from $25 \%$ to over $80 \%$ of $10000 \mathrm{ppm}$ (1\%) $\mathrm{CH}_{4}$, but a higher effectiveness of methane removal was observed only after 100 days of incubation.

The mechanisms of effective removal of methane by raspberry and potato stem biochars haven't been elucidated yet. The pattern of $\mathrm{CH}_{4}$ uptake in our experiment with a multi-day lag phase and a gradual decrease in $\mathrm{CH}_{4}$ concentration may suggest biological oxidation, especially in the case of the newly produced biochars $(\mathrm{Br}$ and $\mathrm{Bp})$. Further evidence for the microbial mechanism of the observed $\mathrm{CH}_{4}$ oxidation may be deduced from the parallel $\mathrm{CO}_{2}$ emission and $\mathrm{O}_{2}$ consumption which were higher at $60 \%$ WHC (Fig. 1). These incubation conditions (including a temperature of $25^{\circ} \mathrm{C}$ ) are widely accepted as optimal for methanotrophic bacteria (Malyan et al., 2016; Skopp et al., 1990; Walkiewicz et al., 2020b). In fact, biochar may contribute to $\mathrm{CO}_{2}$ emissions both biotically (via microbial degradation) and abiotically (via the release of inorganic C contained in the biochar (Gomez et al., 2014; Gul et al., 2015; Jones et al., 2011). In the case of the exclusively physical interaction of biochar with the tested gases, higher $\mathrm{CO}_{2}$ emissions would be expected under full saturation conditions $(100 \% \mathrm{WHC})$. Carbon dioxide binds to oxygen-containing functional groups via hydrogen bonds (Banik et al., 2018). Thus, water molecules and $\mathrm{CO}_{2}$ are likely to adsorb to similar functional groups. As such, the direct competition for active sites between water and $\mathrm{CO}_{2}$ molecules may be observed resulting in higher desorption rates at 100\% WHC (Pytlak et al., 2020). The lower bulk density of the new biochars $(\mathrm{Br}$ and $\mathrm{Bp})$ in comparison with the well-known materials (Bo and Bs) may result in a higher degree of aeration, gas availability and surface area available for microbial colonization (Table 1). In a field experiment described by Noyce et al. (2016) DNA was isolated from biochar which had a long-term (four year) contact with soil. That study showed that biochar was inhabited by similar groups of microorganisms as the adjacent soil. Also, the studies on biochar inoculated with methanogenic Archaea confirm that it may be inhabited by microbes, despite the poor habitat conditions (Schwede et al., 2017).

Along with the advantageous environmental effects of biochar application to soil it is important to consider some economic aspects. Biochar production under anaerobic and high temperature pyrolysis is associated with considerable costs. High energy use leads to adverse environmental consequences as it generates GHGs, mainly $\mathrm{CO}_{2}$ (Fungo et al., 2014). It should be noted, however, that biochar has the ability to remove $\mathrm{CH}_{4}$ which (mole for mole) has a Global Warming Potential several dozen times higher than the $\mathrm{CO}_{2}$ emitted during energy production (Wu et al., 2019). $\mathrm{CO}_{2}$ was also emitted during the incubation time and that allowed for the determination two important biochar parameters. The first is the $\mathrm{CO}_{2} / \mathrm{O}_{2}$ ratio, which may be considered as a biochar stability parameter. A low 
$\mathrm{CO}_{2} / \mathrm{O}_{2}$ ratio indicates higher biochar stability. Accordingly, it may be assumed that biochar from Bp and Bs (at 100\% WHC) were the most stable, while the one originating from Bo showed the lowest stability under both moisture levels. Moreover, $\mathrm{CO}_{2}$ production during biochar incubation were more variable than $\mathrm{O}_{2}$ uptake, which was similar to the results observed by Almeida et al. (2019). The climate change mitigation potential of biochars, may be expressed as the changes in the global warming potential (GWP) of the gases which are either adsorbed or released during incubation. It was observed that the effect of biochars on $\mathrm{CH}_{4}$ and $\mathrm{CO}_{2}$ exchange depended on the feedstock type and moisture level. At 60\% WHC, the change in net GWP in the headspace of potato $(\mathrm{Bp})$ and raspberry $(\mathrm{Br})$ biochar incubations was negative and amounted to -2.187 and $-1.876 \mathrm{~g}$ $\mathrm{CO}_{2}(\mathrm{eq}) \mathrm{kg}^{-1}$, respectively. These values resulted from the great potential of the new biochars to adsorb $\mathrm{CH}_{4}$. For the sunflower husk biochar (Bs) incubations, net GWP was close to zero $\left(0.016 \mathrm{~g} \mathrm{CO}_{2}\right.$ (eq) $\left.\mathrm{kg}^{-1}\right)$ while for the wood offcuts biochar (Bo) it was positive (2.014 $\left.\mathrm{g} \mathrm{CO}_{2}(\mathrm{eq}) \mathrm{kg}^{-1}\right)$ which was a consequence of the highest $\mathrm{CO}_{2}$ production and minimal $\mathrm{CH}_{4}$ absorption. At $100 \% \mathrm{WHC}$, net GWP in incubations with $\mathrm{Bp}$ was characterized by similar negative values $\left(-2.178 \mathrm{~g} \mathrm{CO}_{2}(\mathrm{eq}) \mathrm{kg}^{-1}\right)$ as at lower moisture levels. That confirmed usefulness of $\mathrm{Bp}$, especially for waterlogged ecosystems emitting $\mathrm{CH}_{4}$ into the atmosphere. At higher moisture levels, in the $\mathrm{Br}$ and $\mathrm{Bs}$ headspaces, net GWP was still negative, yet lower, not exceeding -0.5. At both moisture levels studied, Bo incubations were characterized by a strongly positive net GWP $\left(2.122 \mathrm{~g} \mathrm{CO}_{2}(\mathrm{eq})\right.$ $\mathrm{kg}^{-1}$ ) value. The negative net GWP values (Table 3 ) and relatively high $\mathrm{Br}$ and $\mathrm{Bp}$ stability under both moisture levels could be the economic and environmental justification for the application of new biochars. Furthermore, the positive effects of soil enrichment with biochar are long-lasting and apply to many areas, i.e. fertility, hydrological and aeration conditions which result in increased crop productivity and a reduced necessity for agrotechnical practices. The tradeoffs of economic profits and a reduction in GHG emissions should be included in the evaluations of the consequences of biochar application.

Therefore, it is important to continue research with biochars from new materials produced at lower temperatures in order to find optimal pyrolysis parameters to combine the lowest possible economical costs with maintained or even improved expected properties.

\section{CONCLUSIONS}

1. The methane uptake of four biochars was evaluated in a lab experiment. The results showed that two new biochars (from potato and raspberry stems) were able to efficiently remove added $1 \% \mathrm{CH}_{4}$, especially at $60 \%$ water holding capacity.
2. The high $\mathrm{CH}_{4}$ consumption presented by the new biochars has great potential compared to common biochars from wood offcuts or sunflower husks and this could be a way of managing agricultural waste.

3. The advantage of new biochars from raspberry and potato stems over wood offcuts biochar is their significantly lower production of carbon dioxide, yet high methane absorption potential. At $60 \%$ water holding capacity, as well as at $100 \%$ water holding capacity, the potato stem biochar still showed the highest $\mathrm{CH}_{4}$ uptake rates with relatively low $\mathrm{CO}_{2}$ emission and $\mathrm{O}_{2}$ uptake. Hence the potato stem biochar may be a good choice in ecosystems characterized by relatively high methane concentrations, such as periodically flooded and waterlogged areas, landfills or paddy fields.

4. Based on the $\mathrm{CO}_{2} / \mathrm{O}_{2}$ ratio, the biochars from sunflower husks and potato stems (at 100\% water holding capacity) were the most stable, between the materials tested.

5. As a consequence, it is reasonable to carry out both short-term and long-term studies concerning the various sorptions and emissions of gases by these biochars. It should also be considered whether the observed greenhouse gas dynamics are dependent on physical or biological factors. Knowledge concerning the properties of biochars which enhance methane removal could be used to increase the filtration potential of these highly promising materials

Conflict of interest: The authors do not declare conflict of interest.

\section{REFERENCES}

Almeida R.F., Spokas K.A., Teixeira D.B., and La Scala Jr, N., 2019. Biochar insights from laboratory incubations monitoring $\mathrm{O}_{2}$ consumption and $\mathrm{CO}_{2}$ production. Biochar, https://doi.org/10.1007/s42773-019-00021-6

Banik C., Lawrinenko M., Bakshi S., and Laird D.A., 2018. Impact of pyrolysis temperature and feedstock on surface charge and functional group chemistry of biochars. J. Environ. Qual., 47, 452-461. https://doi.org/10.2134/ jeq2017.11.0432

Chistoserdova L. and Kalyuzhnaya M.G., 2018. Current trends in methylotrophy. Trends Microbiol., 26, 703-714. https:// doi.org/10.1016/j.tim.2018.01.011

Coomes O.T. and Miltner B.C., 2017. Indigenous charcoal and biochar production: potential for soil improvement under shifting cultivation systems. L. Degrad. Dev., 28, 811-821. https://doi.org/10.1002/1dr.2500

Farzad S., Taghikhani V., Aminshahidi B., and Lay E.N., 2007. Experimental and theoretical study of the ef fect of moisture on methane adsorption and desorption by activated carbon at 273. 5 K. J. Nat. Gas Chem., 16, 22-30. https:// doi.org/10.1016/s1003-9953(07)60021-8

Fungo B., Guerena D., Thiongo M., Lehmann J., Neufeldt H., and Kalbitz K., 2014. $\mathrm{N}_{2} \mathrm{O}$ and $\mathrm{CH}_{4}$ emission from soil amended with steam-activated biochar. J. Plant Nutr. Soil Sci., 177, 34-38. https://doi.org/10.1002/jpln.201300495 
Gomez J.D., Denef K., Stewart C.E., Zheng J., and Cotrufo M.F., 2014. Biochar addition rate influences soil microbial abundance and activity in temperate soils. Eur. J. Soil Sci., 65, 28-39. https://doi.org/10.1111/ejss. 12097

Gul S., Whalen J.K., Thomas B.W., Sachdeva V., and Deng H., 2015. Physico-chemical properties and microbial responses in biochar-amended soils: Mechanisms and future directions. Agric. Ecosyst. Environ., 206, 46-59. https://doi. org/10.1016/j.agee.2015.03.015

Guo W., Feng L., Wu D., Zhang C., and Tian X., 2019. Effectiveness of flame for preplant pest management in leaf vegetable fields. Horttechnology, 29, 788-794. https://doi. org/10.21273/HORTTECH04341-19

Han X., Sun X., Wang C., Wu M., Dong D., Zhong T., Thies J.E., and Wu W., 2016. Mitigating methane emission from paddy soil with rice-straw biochar amendment under projected climate change. Sci. Rep., 6, 1-10. https://doi. org/10.1038/srep24731

He Y., Zhou X., Jiang L., Li M., Du Z., Zhou G., Shao J., Wang X., Xu Z., Hosseini Bai S., Wallace H., and Xu C., 2017. Effects of biochar application on soil greenhouse gas fluxes: a meta-analysis. GCB Bioenergy, 9, 743-755. https://doi. org/10.1111/gcbb.12376

Huang D., Yang L., Ko J.H., and Xu Q., 2019. Comparison of the methane-oxidizing capacity of landfill cover soil amended with biochar produced using different pyrolysis temperatures. Sci. Total Environ., 693, 133594. https://doi. org/10.1016/j.scitotenv.2019.133594

IPCC, 2014. Climate Change 2014: Synthesis Report. Contribution of Working Groups I, II and III to the Fifth Assessment Report of the Intergovernmental Panel on Climate Change, https://doi.org/10.1017/cbo9781107415416

Jeffery S., Verheijen F.G.A., Kammann C., and Abalos D., 2016. Soil Biology and biochemistry biochar effects on methane emissions from soils: A meta-analysis. Soil Biol. Biochem., 101, 251-258.

https://doi.org/10.1016/j.soilbio.2016.07.021

Jones D.L., Murphy D. V., Khalid M., Ahmad W., EdwardsJones G., and DeLuca T.H., 2011. Short-term biochar-induced increase in soil $\mathrm{CO}_{2}$ release is both biotically and abiotically mediated. Soil Biol. Biochem., 43, 1723-1731. https://doi.org/10.1016/j.soilbio.2011.04.018

Kammann C., Ippolito J., Hagemann N., Borchard N., Cayuela M.L., Estavillo J.M., Fuertes-Mendizabal T., Jeffery S., Kern J., Novak J., Rasse D., Saarnio S., Schmidt H.P., Spokas K., and Wrage-Mönnig N., 2017. Biochar as a tool to reduce the agricultural greenhouse-gas burden-knowns, unknowns and future research needs. J. Environ. Eng. Landsc. Manag., 25, 114-139. https://doi.org /10.3846/16486897.2017.1319375

La H., Hettiaratchi J.P.A., Achari G., Verbeke T.J., and Dunfield P.F., 2018. Biofiltration of methane using hybrid mixtures of biochar, lava rock and compost. Environ. Pollut., 241, 45-54.

https://doi.org/10.1016/j.envpol.2018.05.039
Lehmann J., Rillig M.C., Thies J., Masiello C.A., Hockaday W.C., and Crowley D., 2011. Biochar effects on soil biota - A review. Soil Biol. Biochem., 43, 1812-1836. https://doi. org/10.1016/j.soilbio.2011.04.022

Lehmann J. and Rondon M., 2006. Bio-char soil management on highly weathered soils in the humid tropics. Biological Approaches to Sustainable Soil Systems, 3, 517-530. https://doi.org/10.1201/9781420017113.ch36

Luo Y., Yu Z., Zhang K., Xu J., and Brookes P.C., 2016. The properties and functions of biochars in forest ecosystems. J. Soils Sediments, 16, 2005-2020. https://doi.org/10.1007/ s11368-016-1483-5

Mackay G.R., 2009. New light on a hidden treasure. Rome: FAO, 136, Exp. Agric., 45, 376-376. https://doi.org/10.1017/ s0014479709007686

Malyan S.K., Bhatia A., Kumar A., Gupta D.K., Singh R., Kumar S.S., Tomer R., Kumar O., and Jain N., 2016. Methane production, oxidation and mitigation: A mechanistic understanding and comprehensive evaluation of influencing factors. Sci. Total Environ., 572, 874-896.

https://doi.org/10.1016/j.scitotenv.2016.07.182

Noyce G.L., Winsborough C., Fulthorpe R., and Basiliko N., 2016. The microbiomes and metagenomes of forest biochars. Sci. Rep., 6, 1-12. https://doi.org/10.1038/srep26425

Özçimen D. and Karaosmanoğlu F., 2004. Production and characterization of bio-oil and biochar from rapeseed cake. Renew. Energy, 29, 779-787. https://doi.org/10.1016/j. renene.2003.09.006

PytlakA., Stępniewska Z., Kuźniar A., Szafranek-Nakonieczna A., Wolińska A., and Banach A., 2014. Potential for aerobic methane oxidation in carboniferous coal measures. Geomicrobiol. J., 31, 737-747. https://doi.org/10.1080/014 90451.2014.889783

Pytlak A., Sujak A., Szafranek-Nakonieczna A., Grządziel J., Banach A., Goraj W., Gruszecki W.I., and Stępniewska Z., 2020. Water-induced molecular changes of hard coals and lignites. Int. J. Coal Geol., 224, 103481. https://doi. org/10.1016/j.coal.2020.103481

Qi L., Pokharel P., Ni C., Gong X., Zhou P., Niu H., Wang Z., and Gao M., 2020. Biochar changes thermal activation of greenhouse gas emissions in a rice-lettuce rotation microcosm experiment. J. Clean. Prod., 247. https://doi.org/10.1016/j.jclepro.2019.119148

Reddy K.R., Yargicoglu E.N., Yue D., and Yaghoubi P., 2014. Enhanced microbial methane oxidation in landfill cover soil amended with biochar. J. Geotech. Geoenvironmental Eng., 140, 1-11. https://doi.org/10.1061/(ASCE)GT.1943-5606.0001148

Ribas A., Mattana S., Llurba R., Debouk H., Sebastià M.T., and Domene X., 2019. Biochar application and summer temperatures reduce $\mathrm{N}_{2} \mathrm{O}$ and enhance $\mathrm{CH}_{4}$ emissions in a Mediterranean agroecosystem: Role of biologicallyinduced anoxic microsites. Sci. Total Environ., 685, 1075-1086. https://doi.org/10.1016/j.scitotenv.2019.06.277

Schwede S., Bruchmann F., Thorin E., and Gerber M., 2017. Biological syngas methanation via immobilized methanogenic archaea on biochar. Energy Procedia, 105, 823-829. https://doi.org/10.1016/j.egypro.2017.03.396 
Skopp J., Jawson M.D., and Doran J.W., 1990. Steady-state aerobic microbial activity as a function of soil water content. Soil Sci. Soc. Am. J., 54, 1619-1625. https://doi. org/10.2136/sssaj1990.03615995005400060018x

Sokołowska Z., Szewczuk-Karpisz K., Turski M., Tomczyk A., Cybulak M., and Skic K., 2020. Effect of wood waste and sunflower husk biochar on tensile strength and porosity of dystric cambisol artificial aggregates. Agronomy, 10. https://doi.org/10.3390/agronomy10020244

Spokas K.A. and Reicosky D.C., 2009. Impacts of sixteen different biochars on soil greenhouse gas production. Ann. Environ. Sci., 3, 179-193.

Syed R., Saggar S., Tate K., and Rehm B.H.A., 2016. Assessment of farm soil, biochar, compost and weathered pine mulch to mitigate methane emissions. Appl. Microbiol. Biotechnol., 100, 9365-9379. https://doi.org/10.1007/s00253-016-7794-z

Thomazini A., Spokas K., Hall K., Ippolito J., Lentz R., and Novak J., 2015. GHG impacts of biochar: Predictability for the same biochar. Agric. Ecosyst. Environ., 207, 183-191. https://doi.org/10.1016/j.agee.2015.04.012

Tomczyk A., 2020. Biochar physicochemical properties: pyrolysis temperature and feedstock kind effects. Rev. Environ. Sci. Bio/Technol., 19, 191-215. https://doi.org/10.1007/ s11157-020-09523-3

Vincent C., Hallman G., Panneton B., and Fleurat-Lessard F., 2003. Management of agricultural insects with physical control methods. Annu. Rev. Entomol., 48, 261-281. https:// doi.org/10.1146/annurev.ento.48.091801.112639

Walkiewicz A., Brzezińska M., Wnuk E., and Jabłoński B., 2020a. Soil properties and not high $\mathrm{CO}_{2}$ affect $\mathrm{CH}_{4}$ production and uptake in periodically waterlogged arable soils. J. Soils Sediments, 20, 1231-1240. https://doi.org/10.1007/ s11368-019-02525-x

Walkiewicz A., Kalinichenko K., Kubaczyński A., Brzezińska M., and Bieganowski A., 2020b. Usage of biochar for mitigation of $\mathrm{CO}_{2}$ emission and enhancement of $\mathrm{CH}_{4}$ consumption in forest and orchard Haplic Luvisol (Siltic) soils. Appl. Soil Ecol., 156.

https://doi.org/10.1016/j.apsoil.2020.103711
Wu Z., Song Y., Shen H., Jiang X., Li B., and Xiong Z., 2019. Biochar can mitigate methane emissions by improving methanotrophs for prolonged period in fertilized paddy soils. Environ. Pollut., 253, 1038-1046. https://doi. org/10.1016/j.envpol.2019.07.073

Xiong X., Liu X., Yu I.K.M., Wang L., Zhou J., Sun X., Rinklebe J., Shaheen S.M., Ok Y.S., Lin Z., and Tsang D.C.W., 2019. Potentially toxic elements in solid waste streams: Fate and management approaches. Environ. Pollut., 253, 680-707. https://doi.org/10.1016/j.envpol.2019.07.012

Yang T., Sun W., and Yue D., 2017. Characterizing the effects of biologically active covers on landfill methane emission flux and bio-oxidation. J. Environ. Eng. (United States), 143, 1-9. https://doi.org/10.1061/(ASCE)EE.1943-7870.0001251

Yoo G., Kim H., Chen J., and Kim Y., 2014. Effects of biochar addition on nitrogen leaching and soil structure following fertilizer application to rice paddy soil. Soil Sci. Soc. Am. J., 78, 852-860. https://doi.org/10.2136/sssaj2013.05.0160

Yu L., Tang J., Zhang R., Wu Q., and Gong M., 2012. Effects of biochar application on soil methane emission at different soil moisture levels. Biol. Fertil. Soils, 49. https://doi. org/10.1007/s00374-012-0703-4

Yu Z., Chen L., Pan S., Li Y., Kuzyakov Y., Xu J., Brookes P.C., and Luo Y., 2018. Feedstock determines biocharinduced soil priming effects by stimulating the activity of specific microorganisms. Eur. J. Soil Sci., 69, 521-534. https://doi.org/10.1111/ejss.12542

Zaremba L., 2014. Polish and global market of raspberries and their preserves (in Polish). Zesz. Nauk. Szk. Głównej Gospod. Wiej. w Warszawie Probl. Rol. Światowego, 14(29), 148-156.

Zubkova V., Strojwas A., Bielecki M., Kieush L., and Koverya A., 2019. Comparative study of pyrolytic behavior of the biomass wastes originating in the Ukraine and potential application of such biomass. Part 1. Analysis of the course of pyrolysis process and the composition of formed products. Fuel, 254, 115688.

https://doi.org/10.1016/j.fuel.2019.115688 